\title{
Rhetorical Analysis of Joe Biden's Inauguration Address
}

Neni Nurkhamidah ${ }^{1 凶}$, Raihana Ziani Fahira ${ }^{2}$, Ayu Ratna Ningtyas ${ }^{3}$

${ }^{1}$ English Education Program, STKIP Media Nusantara Citra, Jakarta, Indonesia

${ }^{2}$ English Education Program, STKIP Media Nusantara Citra, Jakarta, Indonesia

${ }^{3}$ Universitas Muhammadiyah Purwokerto, Central Java, Indonesia

凶 email: neni.nurkhamidah@stkipmnc.ac.id

\section{Received: October 13, 2021}

Revised: November 02, 2021

Accepted: November 03, 2021

\begin{abstract}
The inaugural speeches mark the beginning of a new term in office for a community or government leader, such as the president. This reaction must persuade the people to believe in the government and the programs will be enacted. This research aims at finding the rhetorical appeals of President Joe Biden's inaugural address on his inauguration as the 46th President of the United States. The research is based on Aristotle's theory called a rhetorical theory. The resercher employs descriptive qualitative as a methodology to analyze the data from the spoken utterances of the speech. The result shows that Joe Biden uses all of the Aristotelian rhetoric strategies in his inaugural address, which are: ethos, pathos, and logos. The data shows that Joe Biden uses pathos as $55 \%$ of his speech, followed by ethos $37 \%$, and $\log 0$ 8\%.. Joe Biden skillfully used and implied Aristotle's rhetorical theory in his inauguration address to engage and build trust with the American people. From the analysis, the researcher has concluded that a good speaker can use all of the three elements of the rhetorical theory and imply them in the speech or writing.
\end{abstract}

Keywords: Ethos; Inaugural Address; Joe Biden; Logos; Pathos; Rhetorical Analysis.

\section{INTRODUCTION}

On 21 January 2021, Joe Biden the 46th United States of America delivered an inaugural address. In American political history, the Inaugural address has been a tradition marking the beginning works of the new presidency and political transformation from previous presidents to the elected ones. More than an ordinary speech, the inaugural address delivered by some past US presidents intends to inspire and unite the nation. One of the powerful speeches in the US inaugural speech is to ask what you can do for your country as a thesis statement of President John F Kennedy's speech in 1961. This phenomenal word has been inspiring Americans in many ways. Biden's Inauguration is conducted some couple of weeks after terrible chaos in Capitol Building caused by the pro-trump mob. This chaos erupted after Biden's rival, Trump, claimed the election is a fraud. Trump's supporters stormed the building when the congress is verifying Biden's victory. The anarchy, violence, and mockery finally can be controlled by security officials. Five people died in the Capitol attack tragedy including a woman, multiple officers injured, and the congress was evacuated to prevent violence from the protestor. 
The quick spread of news about this incident triggers many people to condemn this tragedy. Some living formers of US presidents also pointed out some comments related to the chaos. George. Bush, in his statement, called what happened in Capitol was an insurrection. He then said that all citizens have to support the law. Barrack Obama called this moment dishonor and shame for the US. Bill Clinton mentioned that the riot was an extraordinary assault on the country, the constitution, and the Capitol. As the riot incited, Trump also instructed his pro-mob to go home peacefully, although he kept pushing that the election was stolen. This riot wrecks American political democracy, but the remark "this is a democracy day" Joe Biden's inauguration speech indicates that American democracy still exists. It is concluded that what happened in the Capitol is the consequence of the language used by Trump on his Twitter and speech that triggered his supporters to storm the Capitol building. And finally, what he did result in impeachment.

An inaugural speech, as one kind of political speech, is an important event for a president to address the public. The speech is mostly delivered in the atmosphere of celebrating the victory. It is an excellent opportunity for the president to persuade and share the ideology with the nation. The inaugural address has been recognized since the United States of America presidency (Shaw, 2017). The communication style used by president on inaugural address has been shifting over time (Stuckey, 2010). Study on the inaugural address is not a new trend. Many kinds of research in this field have been conducted. The interest in analyzing the US president's inaugural address rose because the US president's statements draw the attention of other countries in the world.

This study intends to analyses Aristotle's rhetoric appeals or persuasive art of Joe Biden's inauguration address as the important part of his speech. As the nature of the inaugural address is to persuade people to believe in what the speaker's said, rhetoric study fits with this purpose. The idea of rhetoric or persuasion developed a long time ago by Aristotle called a rhetorical theory. Aristotle argues Rhetoric offers speakers how to build arguments (Floyd-lapp, 2014). This theory is considered relevant and valuable for communication; therefore, rhetoric skill is necessary as the power to persuade the audiences. The researcher realizes that rhetoric study is essential to conduct. The knowledge of rhetoric will be beneficial for many aspects not only in social life but also in classroom interaction and professional careers. It is expected that the result of the study will give the readers insight into how to convince, influence, or persuade the audience effectively to achieve particular goals

Language is seen as the backbone of communication, the vehicle of message transmission, and a potential source of power (Salleh, 2014). Language is a powerful vehicle to express someone's idea in both spoken and written form. There is an intricate relation between language and power (Biria \& Mohammadi, 2012). In a political speech, language plays a crucial role as it builds, establishes and strengths relationship, express idea, and sells programs and policies. That's why it is undeniable that language has been an important issue in politics (Ayeomoni \& Akinkuolere, 2012). To gain power using language, a speaker or a writer has to gain influence from the addressee. An to achieve substantial impact, a person has to be able to express their ideas through either texts or 
talks effectively. For effective verbal communication, owning the language skills is necessary because the power of communication lies in the peoples' language ability. People use language for various fields and different purposes. In the political field, language is very essential because most of the political activities are done through language. They use language for a campaign, presentation, inauguration, and policy formulation (David \& Miracle, 2014).

Rhetoric is recognized as the art of utilyzing the language for persuasion effects (Murthy \& Ghosal, 2014). It is an effective tool to give information, persuade and motivate the audience for particular purposes in specific situations. The successful attempt of using rhetoric on speech has been proven by Mahatma Gandhi, President of India; Martin Luther King, an American activist and Nelson Mandela, President of South Africa that expressed justice and truth to persuade the audiences. Rhetoric is also effective in pursuing a mass, as Oprah Gail Winfrey's Talk Shows prove it. Moreover, the rhetoric in a debate is to see a case from two sides and against a verbal attack.

Aristoteles in Krishnan et al (2020) segmented rhetoric into three groups: ethos, pathos, and logos. Ethos, the art of convincing, is how the projected characters, including credibility and trustworthiness of writer or speaker (Higgins \& Walker, 2012). Pathos is an emotional appeal that persuades listeners to do an action. Gabrielsen \& Christiansen (2010) stated that the emotion or passion for swaying is love, humor, security, love, greed, pity, and guilt. At the same time, Mshvenieradze (2013) added anger, insult, empathy, fear, and confusion as emotional persuasion to affect the audiences. The third, the last Aristotles rhetoric, logos or rational persuasion, is a discourse that presents logic, clarity, rationality, and integrity to an argument (Higgins \& Walker, 2012). This research refers to the Theory of Rhetoric Aristotle as the basis. A brief explanation of the theory can be seen in the following table.

Table 1. Theory of Rhetoric Aristotle in Griffin (2012)

\begin{tabular}{lll}
\hline No & Rhetorical Appeals & Explanation \\
\hline 1 & Ethos & Credibility established by \\
& & audience. Examples: \\
& -Perceived intelligence \\
& -Virtuous character \\
& & -Goodwill \\
\hline 2 & Logos & Reasoning an argument or \\
& & using logic. Examples: \\
& & -Enthymeme \\
& & -Example \\
\hline 3 & Pathos & The feeling or emotion that \\
& persuades people. Examples: \\
& - Anger in contrast to Hatred \\
& -Fear Mildness \\
& -Friendship in contrast to \\
& Hatred \\
& -Fear in contrast to Hatred \\
& -Fear Confidence \\
& -Admiration in contrast to \\
& Hatred \\
& -Fear Envy \\
&
\end{tabular}


Widyawardani (2016), in her analysis of Donald Trump's speech for the US Presidential candidacy announcement, found out that the most dominant rhetoric form of his speech is pathos. And hatred is primarily found in the way he showed his emotions. Mori (2016) with a study on diplomatic discourse conflict at the UN that involved Benjamin Netanyahu, Prime Minister Israel; Hassan Rouhani, the President of Iran; and Mahmoud Abbas, the President of the State of Palestinian revealed that the three speakers employ three types of rhetoric mode. Rouhani primarily operates ethos in his speech to show his character. He also employs logos to describe the United States and Israel injustice acts. Abbas mainly employs pathos in describing the current Palestinians situation; he uses logos and ethos by emphasizing the need to follow international law and agreements. Netanyahu mostly employs logos by describing facts about a potential threat from Iran and emphasizes pathos by warning the danger of Iran to Western countries.

Arofah (2018) found that hate speech rhetorical of Ahok's Religion Blasphemy case in online media mostly implement pathos aspect to persuade the reader; on the other hand, they neglect ethos and logos aspects. Quijano \& Bulusan (2020) explored the rhetorical appeals and devices employed by Presidents Duterte, Presidents Aquino, and Presidents Arroyo on their first state of national address. The study shows that the three presidents mostly use ethos to persuade the audiences. An analysis of Donald Trump's speech in Jerusalem on December 6, 2017, showed that he employs ethos to show his credibility, pathos as statements to raise the audience's feeling and the logos to strengthen his argument (Fanani et al., 2020). In 2018 Orpah Winfrey's gave a commencement speech at the University of Southern California. The analysys of the speech indicated that she employs $63.5 \%$ ethos, $34 \%$ pathos, and $2.5 \%$ logos in her speech (Darminto, 2019). Ethos, as the most dominant she used in her speech intends to establish her credibility by showing her experiences and values to her audiences.

\section{METHOD}

This research intends to explore rhetorical proof used by Joe Biden on his inauguration address based on Aristotle's rhetoric theory. Descriptive qualitative is used to describe the data from spoken utterances. In this study, the researcher is regarded as the main instrument of the research. Ary, Jacobs, \& Sorensen (2010) mentioned that in qualitative research, a human being is a primary instrument to gather and analyze the data. The data is obtained from a transcript of Joe Biden Inauguration Address on 21 January 2021 from Time Magazine. The researcher follows the step of data analysis by Ko (2015). Firstly, the researcher identifies the inaugural address transcripts presented by Joe Biden to examine the theme or issue. Thematic analysis is conducted by breaking down the data into smaller units to be analyzed in descriptive treatment (Vaismoradi et al., 2013).

Descriptive coding is a straightforward coding method to determine descriptive themes. The next step is linking the theme into the Aristotle rhetorical proof that is logos, 
ethos dan pathos. For the data analysis technique, the researcher adopts the table analysis from Widyawardani (2016)

\section{FINDINGS AND DISCUSSION}

The data analysis shows that Joe bidden skillfully employs three Aristotelian rhetoric strategies of ethos, pathos, and logos on his inaugural address to persuade the audiences. As it is shown in figure 1, from 183 sentences being analysed, $55 \%$ is recognized as pathos (101 times), $37 \%$ is ethos (68 times), and $8 \%$ is logos (14 times). Thus far, it is found that studies using Aristotle's rhetoric conception in persuasive discourse have been founded that pathos is employed more than logos and ethos (Hie Ting, 2018). Surprisingly the result of the study is following what has been founded on Ting's research. The result of the study are shown in the following figure.

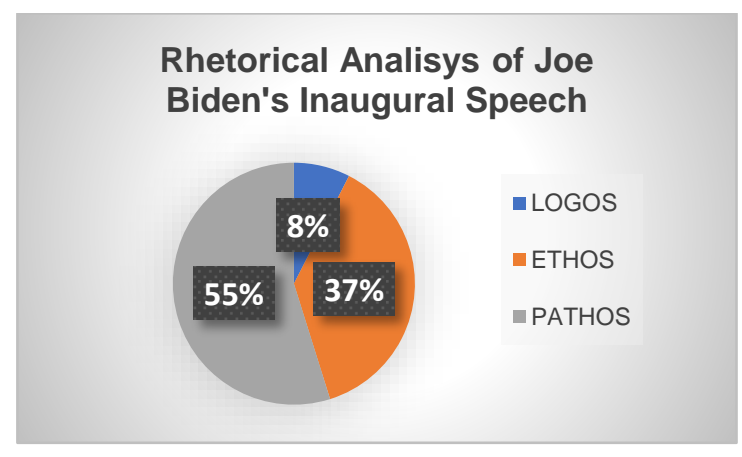

Figure 1. Rhetorical Analysis of Joe Biden's Inaugural Speech

The detail explanation related to the use of each rhetoric will be presented in this part.

\section{Logos}

The first persuasive rhetoric that will be discussed is logos. On his inaugural address, Biden implements 14 logos that consist of 1 enthymeme and 13 examples. An enthymeme is an incomplete argument (Feng \& Hirst, 2011). The missing idea in enthymemes is facts. Aristoteles regards an enthymeme as the strongest among other proofs to persuade the listeners because it engages and initiates cognitive cooperation between people that send and receive the messages. In Biden's inaugural address, the use of enthymemes can be seen in this script.

1."Through a crucible for the ages, America has been tested anew and America has risen to the challenge. Today, we celebrate the triumph not of a candidate, but of a cause, the cause of democracy. The will of the people has been heard and the will of the people has been heeded. We have learned again that democracy is precious. Democracy is fragile." (Biden, 2021)

In script 1, we can find two premises. The first premise is America has many challenges in democracy. The second one is people's voices have been heard and they celebrate the democracy in the inaugural ceremony. Therefore, the conclusion is America overcomes the challenges and democracy wins. This is the only enthymeme employs by Biden. 
Biden mostly uses the example as another way to create audiences' logical reasoning. Biden emphasizes what great things Americans can do by giving examples. Right the wrong, provide a good job for people, manage peaceful education for children, overcome the COVID-19 virus, rebuild the middle class, secure American health and strength racial justice. In different part of his speech, he explains that he will emphasize the urgency and speed in US development. The examples of his programs are to build, to heal, and to restore more in all aspects of American life.

\section{Ethos}

The second rhetorical proof is Ethos. Ethos is an appeal of the speaker's character (Demirdöğen, 2010). Ethos can persuade the audience because the audience judge speaker's intelligence by statements delivered in the speech. To show the speaker is knowledgeable and trustworthy, ethos is important to employ. From 68 logos found in Biden's inaugural speech, it is recognized that he shows his perceived intelligence 31 times, virtuous character 30 times, and goodwill 7 times. Audiences judge the speaker's credibility and competence by statements conveyed in the speech. And they most likely more believe in the credible and competent figure, therefore Biden uses perceived intelligence.

Through this speech, Biden tried to show his intelligence mostly in American History. We can identify this by his effort to observe one of the important moments in American history. He mentions where and when Abraham Lincoln signed the Emancipation Proclamation in detail. By doing this, he expects his audience will consider him as a knowledgeable figure and they will believe in his capability

To create trustworthiness, Biden also emphasizes his virtuous character. He mentions the bible to stress his spiritual side. He points out one message from the bible to show the audience that he is a religious figure. Moreover, he mentions the word God several times. He praises for God and promises in the name of God. In another part of the speech, he also shows his affection for the country, his nationality, his optimism, and his support for equality and peace.

Another element of ethos is goodwill. Goodwill is delivered by giving positive judgment to the audiences. When audiences think that speakers understand, believe, emphasize and responsive to them, they will be more easily to be convinced (Griffin;, 2012). Goodwill is recognized when the speaker compliments, greets or says thanks to the audience. It is also a way to persuade the audience. In his inaugural address, Biden greets the audience in the beginning and in the last of his speech, thanks to the audience several times, emphasizes the audience, and compliments the audience's endurance for unity. The opening of the speech in he greets all audiences to show his goodwill. Biden showed his goodwill towards American's fear and worry on economy. He makes sure that he understands that situation.

\section{Pathos}

The last rhetorical proof is pathos. Pathos is directly linked to the audience to put them in a particular frame of mind. The audience is the subject of speakers trying to be 
persuaded. Therefore, having the audience in the speech is necessary. A good speaker should know which audiences' emotion should be risen by considering several features such as age, social status, and other backgrounds of the audiences (Mshvenieradze, 2013). From 102 pathos made by Biden in his inaugural address, it is indicating that he emphasizes 14 angers, 10 mildness, 26 friendships, 6 fear, 43 confidence, and 2 admiration. He does not employ hate and envy in his speech.

Anger arises because someone feels dissatisfied and irritated. When someone offends us, it also can trigger our anger. In a speech, after showing anger, the speaker usually will give a clear statement by sorry, praise, or show the power. As it is shown in the speech, Biden condemns the Capitol Building attack as an attempt to stop the democracy. He assures that this tragedy will not happen anymore. Biden also shows his anger, but to calm it, he humbles people who do not vote for him in the presidential election and opposition to move forward. Moreover, he adds a milder statement by pointing out how great US power is. If the opponent is still disagreeing with Biden's idea, US democracy will keep running, and the new presidency will work as a mandate of the US constitution.

Biden implements the strategy of persuading audiences by showing friendliness in his inaugural speech. Biden directly mentions that Americans are friends, they are neighbors. He tries to embrace all audiences without judging their race, religion, and other differences because they are one under the US government.

Confidence is the most strategy used by Biden in emotional appeals. The nature of the inaugural speech is to celebrate and introduce the program he will carry out. The whole speech shows Biden has high self-confidence. With his experience and knowledge, he assures the audience to be a fair president for all Americans. We can find Biden's confidence to bring America to a great chapter in history. The better situation than what happened in the past and now. The good condition that many people think is impossible to be manifested.

The last pathos founded in Biden's inaugural address is admiration. Biden mentions President Jimmy Carter as the one he admires. Carter is the 39th president of US that supports civil rights. He is the oldest living former president of the US. He salutes for Charter's lifetime service to the US. Biden also shows his gratitude and admiration for American heroes that have rest in eternal peace in Arlington National Cemetery. Arlington National Cemetery is a place for the last resting place for the American military, national heroes, and many important US historical figures. Biden emphasizes the sacrifice given by all heroes means a lot for the country.

\section{CONCLUSION}

The idea of persuasion or rhetoric is a strong tool to persuade, motivate, and inspiring the audience. The study finds that Joe Biden utilizes all three of Aristotle's appeals of persuasion: ethos, pathos, and logos in his inaugural address with different percentages of each appeal. Pathos are used mostly by Biden, then followed by ethos and logos. Biden implements enthymeme and example in logos. Perceived intelligence, 
virtuous character, and goodwill are employed in ethos. In pathos, he uses anger, mildness, friendships, fear, confidence, and admiration. He does not employ hate and envy in his speech.

Through the analysis of rhetoric appeals, the researcher concludes that a good speaker has to be able to implement ethos, pathos, and logos in a reasonable way to create a strong art of convincing. Thus, English lectures need to emphasize Aristotelian rhetorical theory in speaking class to help students develop practical reasoning, especially on speech, debate, or presentation. A further study on rhetorical theory with a different theory and writing discourse also needs to be conducted to enrich the research variety on this field.

\section{REFERENCES}

Arofah, K. (2018). Rhetorical Analysis of Hate Speech: Case Study of Hate Speech Related to Ahok's Religion Blasphemy Case. Mediator: Jurnal Komunikasi, 11(1), 91105. https://doi.org/10.29313/mediator.v11i1.3119

Ary, D., Jacobs, L. C., \& Sorensen, C. K. (2010). Introduction to Research in Education (8th ed.). Wadsworth.

Ayeomoni, O. M., \& Akinkuolere, O. S. (2012). A Pragmatic Analysis of Victory and Inaugural Speeches of President Umaru Musa Yar" Adua. Theory and Practice in Language Studies, 2(3). https://doi.org/10.4304/tpls.2.3.461-468

Biria, R., \& Mohammadi, A. (2012). The socio pragmatic functions of inaugural speech: A critical discourse analysis approach. Journal of Pragmatics, 44(10), 1290-1302. https://doi.org/10.1016/j.pragma.2012.05.013

Darminto, W. (2019). Rhetorical analysis of Oprah Winfrey's commencement speech at the University of Southern California in 2018. http://lib.unnes.ac.id/34251/1/2201415149_Optimized.pdf

David, W. T., \& Miracle, O. (2014). a Pragmatic Analysis of Victory and Inaugural Speeches of President Jonathan: a Measure for Transformation and Good Governance in Nigeria. 1 (November 2013).

Demirdöğ en, Ü. D. (2016). The Roots of Research in (political) Persuasion: Ethos, Pathos, Logos and the Yale Studies of Persuasive Communications. Undefined.

Fanani, A., Setiawan, S., Purwati, O., Maisarah, M., \& Qoyyimah, U. (2020). Donald Trump's grammar of persuasion in his speech. Heliyon, 6(1), e03082. https://doi.org/10.1016/j.heliyon.2019.e03082

Feng, V. W., \& Hirst, G. (2011). Classifying arguments by scheme. ACL-HLT 2011 Proceedings of the 49th Annual Meeting of the Association for Computational Linguistics: Human Language Technologies, 1, 987-996.

Floyd-lapp, C. (2014). Aristotle's Rhetoric : The Power of Words and the Continued 
Relevance of Persuasion. Young Historians Conference, 1-13.

Gabrielsen, J., Christiansen, T. J., Lange, E. F., \& CLM Translation. (2010). The power of speech (1st ed.). Hans Reitzels Forlag.

Griffin;, E. (2012). A First Look at Communication Theory (Eighth Edition). $/ /$ elibrary.1spr.edu/index.php?p=show_detail\&id=841\&keywords=

Hie Ting, S. (2018). Ethos, Logos and Pathos in University Students' Informal Requests. GEMA Online ${ }^{\circledR}$ Journal of Language Studies, 18(1), 234-251. https://doi.org/10.17576/gema-2018-1801-14

Higgins, C., \& Walker, R. (2012). Ethos , logos , pathos : Strategies of persuasion in social/environmental reports. Accounting Forum, 36(3), 194-208. https://doi.org/10.1016/j.accfor.2012.02.003

Isai, K. I. A., Lin, T. M., Ching, H. S., Selvajothi, R., \& Maruthai, E. (2020). Using Rhetorical Approach of Ethos, Pathos and Logos by Malaysian Engineering Students in Persuasive Email Writings. Malaysian Journal of Social Sciences and Humanities (MJSSH), 5(4), 19-33. https://doi.org/10.47405/mjssh.v5i4.386

Ko, H. (2015). Political Persuasion : Adopting Aristotelian Rhetoric in Public Policy Debate Strategies. International Journal of Humanities and Social Science, 5(10), 114 123.

Mori, K. (2016). Analysis of the discourse of diplomatic conflict at the UN: Application of ethos, pathos, logos. Proceedings of 12 th International Conference on Humanities \& Social Sciences 2016 (IC-HUSO 2016). https://media.neliti.com/media/publications/322734-using-rhetorical-approachof-ethos-patho-2974881a.pdf

Mshvenieradze, T. (2013). Logos Ethos and Pathos in Political Discourse. Theory and Practice in Language Studies, 3(11). https://doi.org/10.4304/tpls.3.11.1939-1945

Murthy, D. M. L., \& Ghosal, D. M. (2014). D. Madhavi Latha Murthy a Study on Aristotle'S Rhetoric. Research Journal of English Language and Literature (RJELAL), 2(4), 249-255. http://www.rjelal.com

Quijano, M. G., \& Bulusan, F. (2020). Language and politics: Exploring the rhetorical appeals and devices employed by three Philippine presidents in their first state of the nation addresses. Asian ESP Journal, 16(21), 31-49. https://www.researchgate.net/publication/341869281_Language_and_Politics_E xploring_the_Rhetorical_Appeals_and_Devices_Employed_by_three_Philippine_ Presidents_in_their_First_State_of_the_Nation_Addresses

Salleh, L. M. (2014). POWER OF LANGUAGE. Prosiding Seminar Antarabangsa Kelestarian Insan 2014 (INSAN2014), 1-10.

Shaw, K. (2017). Beyond the bully pulpit: Presidential speech in the courts. Texas Law 
Rhetorical Analysis of...

Review, 96(1), 71-140.

Stuckey, M. E. (2010). Rethinking the Rhetorical Presidency and Presidential Rhetoric1.

Review of Communication, 10(1), 38-52.

https://doi.org/10.1080/15358590903248744

Vaismoradi, M., Turunen, H., \& Bondas, T. (2013). Content analysis and thematic analysis: Implications for conducting a qualitative descriptive study. Nursing and Health Sciences, 15(3), 398-405. https://doi.org/10.1111/nhs.12048

Widyawardani, Y. I. (2016). Rhetorical analysis of Donald Trump`s Presidential candidacy announcement speech. 